Nigerian Journal of Physiological Sciences 23 (1-2): 115 -120 @Physiological Society of Nigeria, 2008

Available online/abstracted at http://www.bioline.org.br/np; www.ajol.info/journals.nips; www.cas.org

\title{
THE VASORELAXANT EFFECT OF VISCUM ALBUM LEAF EXTRACT IS MEDIATED BY CALCIUM-DEPENDENT MECHANISMS
}

\author{
F. B. O. MOJIMINIYI ${ }^{1}$, M. E. OWOLABI ${ }^{2}$, U. V. IGBOKWE ${ }^{1}$ AND O. P. AJAGBONNA ${ }^{3}$ \\ ${ }^{I}$ Departments of Physiology, Veterinary Physiology \& Pharmacology ${ }^{3}$ Usman Danfodio University, PMB 2254, \\ Sokoto, Nigeria ${ }^{2}$ Department of Pharmaceutical Chemistry, Faculty of Pharmacy, University of Lagos, Nigeria E- \\ mail: mojiminiyi@yahoo.co.uk
}

\begin{abstract}
Summary: Viscum album leaf extract has a folk reputation as an antihypertensive agent in Nigeria. Evidence suggests that it has a relaxant effect on smooth muscle. The present study was designed to investigate the role of calcium in the vasorelaxant effect of this extract. Concentration response studies to noradrenaline, $\mathrm{KCl}$ and $\mathrm{CaCl}_{2}$ were carried out in rat aortic rings with and without the extract in physiological salt solution ( $\mathrm{n}=6$ each). Also the role of intracellular calcium mobilisation was studied by measuring the phasic response to noradrenaline in $\mathrm{Ca}^{2+}$-free EGTA physiological salt solution $(\mathrm{n}=6)$. The contractile responses to noradrenaline or $\mathrm{KCl}$ were attenuated $(\mathrm{P}<0.05)$ and shifted to the right in the presence of the extract. Also the contractile response to $\mathrm{CaCl}_{2}$ in the presence of noradrenaline or $\mathrm{KCl}$ was attenuated $(\mathrm{P}<0.05)$ and shifted to the right, while the phasic response to noradrenaline was significantly $(\mathrm{P}<0.05)$ diminished These results suggest that the vasorelaxant effect of Viscum album extract may be mediated by a non-specific non-competitive inhibition of $\mathrm{Ca}^{2+}$ influx as well as inhibition of $\mathrm{Ca}^{2+}$ mobilization from intracellular stores. This implies that it may contain vasorelaxant agents that may have calcium antagonistic potential.
\end{abstract}

Key words: $\mathrm{Ca}^{2+}$; Vasorelaxant activity; Viscum album, .EGTA, $\mathrm{KCl}$

\section{Introduction}

The extract of the leaves of Viscum album (mistletoe; family: Loranthaceae) has been used for centuries in traditional medicine in many parts of the world. Studies suggest that it has a variety of biological effects. These include anticancer and immune stimulating properties (Grossarth-Maticek and Ziegler, 2006a and b; Zuzak et al., 2006; Lyu and Park, 2006; Ye et al., 2006; Maldacker, 2006; Harmsma et al., 2006), cardioactive (Tenorio-Lopez et al., 2006), vasorelaxant (Ekpenyong et al., 1999) and gastro-intestinal smooth muscle relaxant actions (Adeyemi , Okpo and Adepoju, 1996). In Europe a mistletoe preparation called Iscador has been reported to be effective in the treatment of cancer (Grossarth-Maticek and Ziegler, 2006a and b; Maldacker, 2006; Harmsma et al., 2006). In Nigeria, the extract of the leaves of $V$. album is used in traditional medicine for the treatment of several ailments including hypertension (Adeyemi, Okpo and Adepoju,1996). Indeed a preparation of $V$. album leaves packaged as "nacu tea" has been shown to exhibit a non-specific relaxant and a possible calcium antagonist activity in isolated gastrointestinal (GIT) smooth muscle preparations (Adeyemi , Okpo and Adepoju, 1996). Its vasorelaxant (Ekpenyong et al., 1999) effect and its reduction of coronary vascular resistance (Tenorio-Lopez et al., 2006) suggest that it may have vasodilator properties. It has been shown that the vasorelaxant effect is endothelium dependent involving the release of nitric oxide and not prostacyline (Ekpenyong et al., 1999). However, the extract showed relaxant effect in endotheliumdenuded preparations (Ekpenyong et al., 1999) suggesting that it might also act directly on the vascular smooth muscle via calcium-dependent mechanisms.

The contractile mechanism in smooth muscle is activated by a rise in the concentration of free intracellular $\mathrm{Ca}^{2+}$ concentration ( $\left[\mathrm{Ca}^{2+}\right] \mathrm{i}$; Bohr, 1963; Somlyo and Somlyo, 1968; Bohr, 1973). The source of $\left[\mathrm{Ca}^{2+}\right] \mathrm{i}$ is of dual origin: influx from the extracellular fluid or release from internal pools (Bohr, 1963; Bohr, 1973). Thus, vascular smooth muscle relaxant agents may produce their effects by inhibiting either or both sources of $\mathrm{Ca}^{2+}$ (Ebeigbe and Aloamaka, 1985). Consequently, this study was designed to test the hypothesis that $V$. album may exert its smooth muscle relaxant effect by inhibiting $\mathrm{Ca}^{2+}$ influx or its release from the cellular stores.

\section{Materials and Methods \\ Plant collection and extract preparation}

Fresh leaves of $V$. album were harvested as a parasitic plant on the oil palm tree (Elaies guinensis) at Ago-Iwoye, Ogun State, Nigeria and identified by Professor Olowokudejo of the Botany Department, 
University of Lagos, Nigeria. The fresh leaves were dried at room temperature for two weeks and then ground into fine powder. $500 \mathrm{~g}$ of the powder was extracted with 5 litres of distilled water using a soxhlet extractor for 48 hours. The aqueous extract obtained was concentrated to dryness using a freeze dryer to yield $98 \mathrm{~g}$ of lyophilized extract. The extract constituted about $19.6 \%$ of the weight of the original material. It was stored at $4^{\circ} \mathrm{C}$ until it was used for the experiments. The samples used for each experiment were freshly prepared daily by dissolving appropriate weights of the extract in distilled water.

Preparation of aortic rings

Adult male Sprague-Dawley rats weighing 200$260 \mathrm{~g}$ were killed by cervical dislocation and the thoracic aorta quickly exposed, carefully cleaned of fat and immediately placed in a Petri dish containing physiological salt solution (PSS) of the following composition (mmol. $\mathrm{I}^{-1}$ ): $\mathrm{NaCl}, 119 ; \mathrm{KCl}, 4.7$; KH${ }_{2} \mathrm{PO}_{4}, 1.2 ; \mathrm{MgSO}_{4}, 1.2 ; \mathrm{NaHCO}_{3}, 14.9 ; \mathrm{CaCl}_{2}, 1.6$; glucose, 11.5. The aorta was cut into $2 \mathrm{~mm}$ ring segments. Each aortic ring was mounted between two hooks suspended in a $20 \mathrm{ml}$ jacketed tissue bath containing PSS. The hook was anchored onto the base of the organ bath while the rod was connected to a Grass FTO3 force transducer (FT.O3; Grass Instruments, Quincy, MA, USA) for the measurement of changes in isometric contraction (Obiefuna et al., 1991; Obiefuna, Sofola and Ebeigbe, 1991; Adegunloye and Sofola, 1997). The recording was displayed on a 4-channel Grass model 7D polygraph (model 7D; Grass Instruments, Quincy, Mass., USA). The PSS in the organ bath was continuously bubbled $\begin{array}{lllll}\text { with a } & 95 \% & \mathrm{O}_{2}-5 \% & \mathrm{CO}_{2} & \text { gas mixture and the }\end{array}$ temperature and $\mathrm{pH}$ were maintained at $37^{\circ} \mathrm{C}$ and 7.4 respectively (Obiefuna et al., 1991; Obiefuna, Sofola and Ebeigbe, 1991; Adegunloye and Sofola, 1997).

Each aortic ring was under a passive tension of $2 \mathrm{~g}$. They were equilibrated or stabilized for 90 minutes during which they were stimulated for 3-5 minutes with $10^{-7}$ mol. $1^{-1}$ noradrenaline at 30 minute intervals (Obiefuna et al., 1991; Obiefuna, Sofola and Ebeigbe, 1991; Adegunloye and Sofola, 1997). In experiments requiring high concentrations of $\mathrm{KCl}$, high- $\mathrm{K}^{+}$PSS was prepared by equimolar substitution of $\mathrm{NaCl}$ with $\mathrm{KCl}$.

\section{Relaxation response studies to $V$. album}

At the end of the 90 minute stabilization period the rings were pre-contracted with $10^{-7}$ mol. $\mathrm{l}^{-1}$ noradrenaline or $60 \mathrm{mmol}^{-1} \mathrm{KCl}$. After the contraction had peaked $V$. album $(2-16 \mathrm{mg} / \mathrm{ml})$ was added cumulatively into the bath. The effect of each concentration was allowed to stabilize before the addition of the next concentration. The $\mathrm{IC}_{50}$ of $V$. album in noradrenaline pre-contracted rings was 5.2 $\pm 0.79 \mathrm{mg} / \mathrm{ml}$ while the $\mathrm{IC}_{25}$ in $\mathrm{KCl}$ pre-contracted rings was $7.1 \pm 0.56 \mathrm{mg} / \mathrm{ml}$. These concentrations of $V$. album were used in subsequent experiments detailed below. The $\mathrm{IC}_{25}$ was used for the experiments with $\mathrm{KCl}$ because the calculated $\mathrm{IC}_{50}$ in $\mathrm{KCl}$ precontracted rings was very high and might not be achievable in the tissue bath.

\section{Concentration response studies to noradrenaline and $\mathrm{KCl}$.}

The rings were exposed to cumulative concentrations of noradrenaline $\left(10^{-9}\right.$ to $\left.10^{-5} \mathrm{~mol} . \mathrm{l}^{-1}\right)$ after incubating with the vehicle $(0.2 \mathrm{ml}$ distilled water) for 15 minutes and the contractile responses recorded. The tissues were washed by flushing with PSS at 15 minute intervals several times until the pen returned to baseline. After adequate rest the tissues were incubated with the extract $(5.2 \mathrm{mg} / \mathrm{ml})$ for 15 minutes and the concentration response study to noradrenaline repeated. The same procedure was used for the concentration response study to $\mathrm{KCl}$ (10$\left.80 \mathrm{mmol} . \mathrm{l}^{-1}\right)$ with and without the extract $(7.1 \mathrm{mg} / \mathrm{ml})$ in another set of freshly stabilized aortic rings.

\section{Concentration response to $\mathrm{CaCl}_{2}$}

Aortic rings were stimulated with $10^{-5} \mathrm{~mol}^{-1} \mathrm{l}^{-1}$ noradrenaline in normal PSS. After the contraction had peaked, the normal PSS was substituted with Cafree PSS containing $1 \mathrm{mmol} . \mathrm{l}^{-1}$ EGTA for 30 minutes. Midway into this period the tissue was stimulated with $10^{-5}$ mol. $1^{-1}$ noradrenaline to further deplete its calcium stores. At the end of 30 minutes the Ca-free EGTA PSS was replaced with Ca-free PSS without EGTA after which $10^{-5}$ mol. $1^{-1}$ noradrenaline was added, to open the ligand-gated $\mathrm{Ca}^{2+}$ channels (Obiefuna et al., 1991) followed almost immediately by the addition of $0.2 \mathrm{ml}$ of the vehicle or extract $(5.2 \mathrm{mg} / \mathrm{ml})$. The tissues were incubated with the vehicle or extract for 15 minutes and then $\mathrm{CaCl}_{2}(2.5$ $\mathrm{x} 10^{-4}$ to $1.6 \times 10^{-1}$ mol. $\mathrm{l}^{-1}$ ) was added cumulatively (Sofola, Obiefuna and Adegunloye, 1993; Adegunloye, Sofola and Coker, 1993).

Concentration response to $\mathrm{CaCl}_{2}$ was carried out in a different set of freshly stabilized aortic rings with or without the extract $(7.1 \mathrm{mg} / \mathrm{ml})$ using the above protocol. However $80 \mathrm{mmol} . \mathrm{l}^{-1} \mathrm{KCl}$ was used to open the voltage-gated $\mathrm{Ca}^{2+}$ channels before the cumulative addition of $\mathrm{CaCl}_{2}$.

\section{Phasic contraction to Noradrenaline}

Phasic contraction to $10^{-5}$ mol. $\mathrm{l}^{-1}$ noradrenaline was carried out in Ca-free EGTA PSS (Ebeigbe and Aloamaka, 1985; Perry and Webb, 1991; Sofola, Obiefuna and Adegunloye, 1993; Adegunloye, Sofola and Coker, 1993). The tissues were stimulated with $10^{-5}$ mol. $1^{-1}$ noradrenaline in normal PSS. At the peak 
of the contraction the normal PSS was replaced with Ca-free PSS containing $1 \mathrm{mmol}^{-1} \mathrm{l}^{-1}$ EGTA for 10 minutes in order to deplete the cellular stores of calcium. This was followed by incubation of the rings in PSS containing $2 \mathrm{mmol}^{-1} \mathrm{CaCl}_{2}$ for another 10 minutes (calcium loading) after which this was substituted with Ca-free EGTA PSS and incubated with vehicle or $V$. album $(5.2 \mathrm{mg} / \mathrm{ml})$ for 15 minutes before they were stimulated with $10^{-5}$ mol. $1^{-1}$ noradrenaline and the contractile response recorded. Such phasic contraction is a useful index of $\mathrm{Ca}^{2+}$ mobilization from intracellular stores (Ebeigbe and Aloamaka, 1985; Perry and Webb, 1991; Sofola, Obiefuna and Adegunloye, 1993; Adegunloye, Sofola and Coker, 1993).

\section{Drugs}

Drugs used in this study were noradrenaline (arterenol) and $\mathrm{N}^{\prime} \mathrm{N}^{\prime}$-ethylene glycol tetraacetic acid (EGTA). Both were from Sigma. The drugs were diluted in distilled water. They were freshly prepared on the day of the experiment.

\section{Statistical Analysis}

The results are presented as mean \pm SEM. The $\mathrm{IC}_{50}$ or $\mathrm{IC}_{25}$ was computed using a programme for logit transformation of concentration response curves (CRCs; Obiefuna et al., 1991; Obiefuna, Sofola and Ebeigbe, 1991; Adegunloye and Sofola, 1997). The student's t test for paired data was used for statistical analysis. $\mathrm{P}<0.05$ was taken as statistically significant.
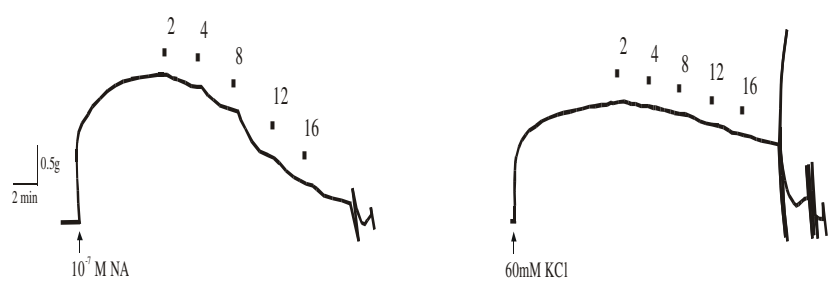

Fig.1. Typical tracings of relaxation responses to graded concentrations of $V$. album $(2-16 \mathrm{mg} / \mathrm{ml})$ recorded in aortic rings pre-contracted with $10^{-7} \mathrm{M}$ noradrenaline (NA) or $60 \mathrm{mM} \mathrm{KCl}$.

\section{Results}

Relaxation response to $V$. album

Fig 1 shows typical tracings of relaxation responses to $V$. album recorded in aortic rings precontracted with noradrenaline or $\mathrm{KCl}$.

Concentration response to noradrenaline and $\mathrm{KCl}$.

The concentration response of aortic rings to noradrenaline with and without $V$. album is shown in Figure 2. The curve obtained in the presence of $V$. album was significantly shifted to the right and attenuated compared to the control curve $(\mathrm{P}<0.05)$. The concentration response curve to $\mathrm{KCl}$ in the presence $V$. album was also significantly shifted to the right and attenuated compared to the control curve $(\mathrm{P}<0.05$; Figure 3$)$.

\section{Concentration response to $\mathrm{CaCl}_{2}$}

The concentration response curves to $\mathrm{CaCl}_{2}$ in the presence and absence of $V$. album following stimulation by $10^{-5}$ mol. $1^{-1}$ noradrenaline and 80 mmol..$^{-1} \mathrm{KCl}$ respectively are shown in Figures 4 and 5. Again the curves were significantly shifted to the right and attenuated in the presence of $V$. album $(\mathrm{P}<0.05)$.

\section{Phasic contraction to Noradrenaline}

The phasic contraction to noradrenaline in the presence of $V$. album was significantly lower than that in its absence $(\mathrm{P}<0.05$; Figure 6$)$.

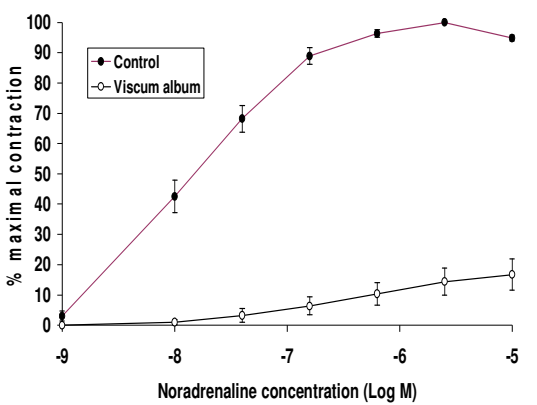

Fig.2. Concentration response curves for noradrenaline in aortic rings incubated with and without $V$. album $(5.2 \mathrm{mg} / \mathrm{ml})$. Each point represents mean \pm SEM of 6 experiments. $P<0.05$ at all concentrations. 


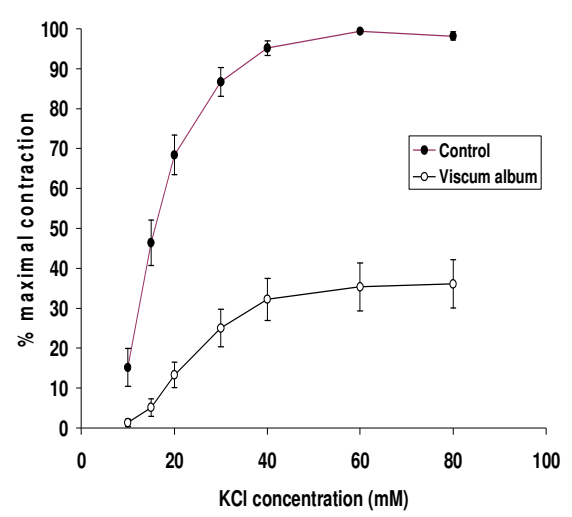

Fig. 3. Concentration response curves for $\mathrm{KCl}$ in aortic rings in the absence (control) and following exposure to $V$. album $(7.1 \mathrm{mg} / \mathrm{ml})$. Each point represents mean $\pm S E M$ of 6 experiments. $P<0.05$ at all concentrations.

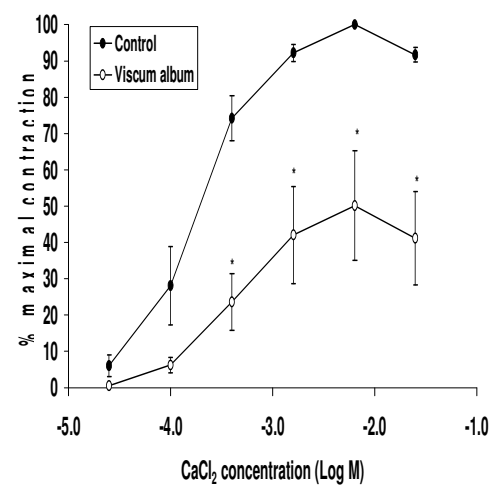

Fig. 4. Concentration response curves for $\mathrm{CaCl}_{2}$ in aortic rings incubated with and without $V$. album $(5.2 \mathrm{mg} / \mathrm{ml})$ following opening of ligand-gated channels with $10^{-5} \mathrm{M}$ noradrenaline. Each point represents mean \pm SEM of 6 experiments. $* P<0.05$.

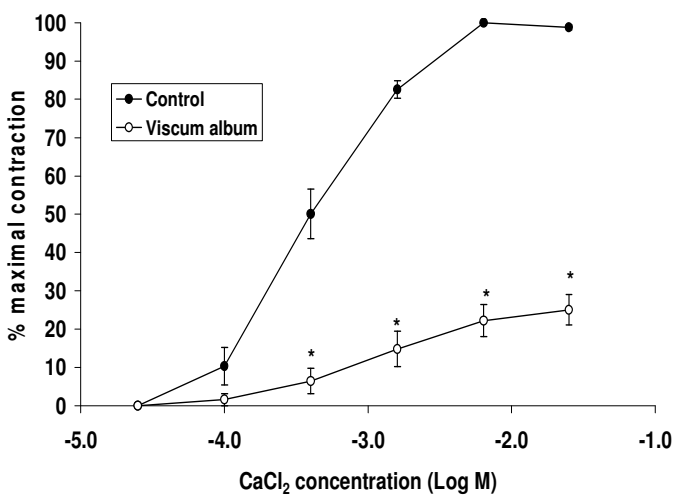

Fig. 5. Concentration response curves for $\mathrm{CaCl}_{2}$ in aortic rings incubated with and without $V$. album $(7.1 \mathrm{mg} / \mathrm{ml})$ following opening of voltage-gated channels with $80 \mathrm{mM}$ $K C l$. Each point represents mean \pm SEM of 6 experiments. $* P<0.05$.

\section{Discussion}

The major finding of this study is that the aqueous leaf extract of $V$. album has a vasorelaxant effect that is mediated by $\mathrm{Ca}^{2+}$-dependent mechanisms. Relaxation of noradrenaline and $\mathrm{KCl}$ pre-contracted aortic rings by the extract suggests that its relaxant effect is non-specific. However noradrenaline precontraction appeared to be more susceptible to $V$. album than $\mathrm{KCl}$ pre-contraction (Figure 1) as evidenced by the $\mathrm{IC}_{50}$ and $\mathrm{IC}_{25}$ value obtained respectively. Indeed $\mathrm{IC}_{25}$ was used for subsequent experiments with $\mathrm{KCl}$ because the calculated $\mathrm{IC}_{50}$ value obtained from the relaxation response experiments was very high. Such concentrations may not be suitable in small tissue baths used in this study.

The results show that the contractile responses to noradrenaline and $\mathrm{KCl}$ were attenuated by the extract as evidenced by the shifting of concentration response curve (CRC) of each contractile agent to the right and the depression of its maximal response in the presence of $V$. album. A similar pattern was observed in the CRCs to $\mathrm{CaCl}_{2}$ in the presence of $V$. album following the opening of $\mathrm{Ca}^{2+}$-channells by noradrenaline or $\mathrm{KCl}$ (Figures 4 and 5). Taken together, these observations are suggestive of noncompetitive antagonism (Furchgott, 1966). The contractile mechanism in smooth muscle is activated by a rise in the concentration of free intracellular $\mathrm{Ca}^{2+}$ concentration $\left(\left[\mathrm{Ca}^{2+}\right] \mathrm{i}\right.$; Bohr, 1963; Somlyo and Somlyo, 1968; Bohr, 1973). This may occur via $\mathrm{Ca}^{2+}$ influx through ligand-gated or voltage-gated $\mathrm{Ca}^{2+}$ channels (Bohr, 1963; Somlyo and Somlyo, 1968; Bohr, 1973) which were opened by the use of noradrenaline and $\mathrm{KCl}$ respectively in this study. Consequently, the present findings suggest that that the reduction in contractile response to these agonists by $V$. album may be through a non-specific noncompetitive antagonistic action on $\mathrm{Ca}^{2+}$ influx.

However, since increase in $\left[\mathrm{Ca}^{2+}\right] \mathrm{i}$ may also occur through release from cellular stores the effect of $V$. album on this was studied by measuring the phasic response to noradrenaline. Such phasic contraction is a useful index of $\mathrm{Ca}^{2+}$ mobilization from intracellular stores (Ebeigbe and Aloamaka, 1985; Perry and Webb, 1991; Sofola, Obiefuna and Adegunloye, 1993; Adegunloye, Sofola and Coker, 1993). The results of the present study show that phasic response to noradrenaline in $\mathrm{Ca}^{2+}$-free EGTA PSS was attenuated by the extract. This suggests that mobilization of intracellular $\mathrm{Ca}^{2+}$ for contraction by noradrenaline was inhibited. 


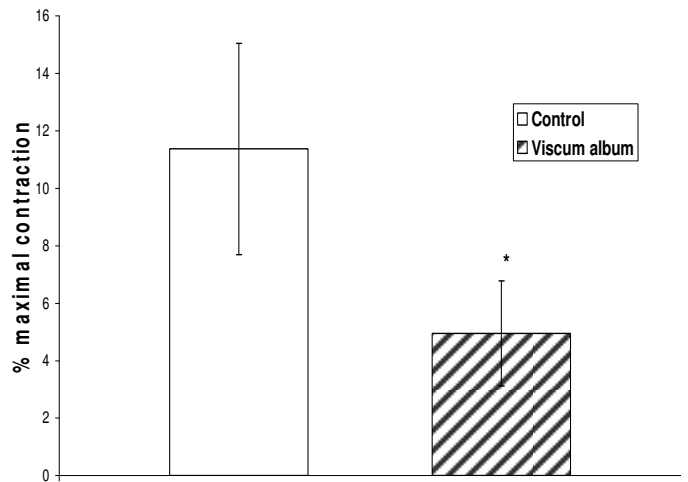

Fig. 6. Bar graphs showing the effect of V. album $(5.2 \mathrm{mg} / \mathrm{ml})$ on phasic contraction to noradrenaline in calcium-free PSS. $n=6$ experiments. $* P<0.05$

These results are consistent with an earlier study suggesting that a $V$. album preparation showed a nonspecific relaxant and calcium antagonist activity in isolated gastrointestinal tract (GIT) smooth muscle preparations (Adeyemi , Okpo and Adepoju, 1996).

However, it is possible that $V$. album may effect its vasorelaxant action through other mechanisms as well. Earlier reports suggest that its vasorelaxant effect was endothelium dependent (Ekpenyong et al., 1999) occurring through the nitric oxide/soluble guanylate cyclase pathway (Ekpenyong et al., 1999; Tenorio-Lopez et al., 2006). Indeed since endothelium intact preparations were used in this study, some of the actions on $\mathrm{Ca}^{2+}$ influx or mobilization from cellular stores observed in this study for $V$. album may be partly mediated by nitric oxide (NO). This is because NO inhibits $\mathrm{Ca}^{2+}$ influx through ligand gated $\mathrm{Ca}^{2+}$ channels as well as release from cellular stores. Thus it is conceivable that $V$. album may achieve vasorelaxation through stimulation of the nitric oxide/soluble guanylate cyclase pathway as well as through $\mathrm{Ca}^{2+}$-dependent mechanisms. These dual mechanisms suggest that $V$. album may be useful in the treatment of hypertension. Hypertension is characterized by an increase in peripheral resistance which may be due to elevated $\left[\mathrm{Ca}^{2+}\right] \mathrm{i}$ and/or endothelial dysfunction. $V$. album may be useful in its treatment conceivably by ameliorating these defects. However actual experiments will be needed to confirm this notion. In spite of this, the present findings provide some evidence suggesting that the use of this extract in Nigerian folk medicine for the treatment of hypertension may be justified.

In summary, this study was designed to investigate the role of calcium in the vasorelaxant effect of $V$. album. The contractile responses to noradrenaline and $\mathrm{KCl}$ were attenuated and shifted to the right in the presence of the extract. Also the contractile response to $\mathrm{CaCl}_{2}$ in the presence of each agent (noradrenaline or $\mathrm{KCl}$ ) was attenuated and shifted to the right, while the phasic response to noradrenaline was diminished. These results suggest that the vasorelaxant effect of $V$. album extract may be mediated by a non-specific non-competitive inhibition of $\mathrm{Ca}^{2+}$ influx as well as inhibition of $\mathrm{Ca}^{2+}$ mobilisation from intracellular stores. This study may provide a scientific basis for the use of this extract in Nigerian traditional medicine for the treatment of hypertension.

\section{Acknowledgements}

We wish to thank Mr. E. Sibigam for preparing the typical tracings and Dr. R.R. Ettarh for drawing the line graphs.

\section{References}

Adegunloye, B. J. and Sofola, O. A. (1997). Effect of dietary salt loading and high calcium diet on vascular smooth muscle responses and endothelium function in rats. Clin. Exp. Pharmacol. Physiol. 24: 814-818.

Adegunloye, B. J., Sofola, O. A. and Coker, H. A. B. (1993). Relaxant effect of mefloquine on vascular smooth muscle in vitro. Eur. J. Clin. Pharmacol. 45: 85-88.

Adeyemi, O. O., Okpo, S. O. and Adepoju, S. R. (1996). Non-Specific smooth muscle relaxant and calcium antagonist activity of "nacu tea": a Viscum album preparation. Niger. Quart. J. Hosp. Med. 6: 229-235.

Bohr, D. F. (1963). Vascular smooth muscle: Dual effect of calcium. Science 139: 597-599.

Bohr, D.F. (1973). Vascular smooth muscle updated. Circ. Res. 32: 665-672.

Collins, P., Griffith, T. M., Henderson, A. H. and Lewis, M. J. (1986). Endothelium-derived relaxing factor alters calcium fluxes in rabbit aorta: a cyclic guanosine monophophatemediated effect. J. Physiol. (Lond) 381: 427437.

Ebeigbe, A. B. and Aloamaka, C. P. (1985). Mechanism of hydralazine-induced relaxation of arterial smooth muscle. Cardiovascular Res. 19: 400-405.

Ekpenyong, M. E., Mojiminiyi, F., Egwuatu, O. C. and Coker, H. A. B. (1999). Relaxant effect of the aqueous leaves extract of Viscum album in rat aortic rings. J. Pharm. Sci. Pharm. Pract. 5: $38-42$.

Furchgott, R. F. (1966). The use of $\beta$ haloalkylamines in the differientiation of receptors and in the determination of 
dissociation constants of receptor-agonist complexes. In: N.J. Harper and A.B. Simmonds (eds.). Advances in Drug Research. Academic Press, London. volume 3 pp. 21-55.

Grossarth-Maticek, R.and Ziegler, R. (2006a). Randomised and non-randomised prospective controlled cohort studies in matched-pair design for the long-term therapy of breast cancer patients with a mistletoe preparation (Iscador): a re-analysis. Eur. J. Med. Res. 11: 485-95.

Grossarth-Maticek, R. and Ziegler, R. (2006b). Prospective controlled cohort studies on longterm therapy of breast cancer patients with a mistletoe preparation (Iscador). Forschende Komplementarmedizin 13: 285-92.

Harmsma, M., Ummelen, M., Dignef, W., Tusenius, K.J. and Ramaekers, F.C. (2006). Effects of mistletoe (Viscum album L.) extracts Iscador on cell cycle and survival of tumor cells. Arzneimittel-Forschung 56: 474-82.

Lyu, S.Y. and Park, W.B. (2006). Mistletoe lectin (Viscum album coloratum) modulates proliferation and cytokine expressions in murine splenocytes. J. Biochem. Mol. Biol. 39: 662670.

Maldacker, J. (2006). Preclinical investigations with mistletoe (Viscum album L.) extract Iscador. Arzneimittel-Forschung 56: 497-507.

Obiefuna, P. C. M., Ebeigbe, A. B., Sofola, O. A. and Aloamaka, C. P. (1991). Altered responses of aortic smooth muscle from Sprague-Dawley rats with salt-induced hypertension. Clin. Exp. Pharmacol. Physiol. 18: 813-818.

Obiefuna, P. C. M., Sofola, O. A. and Ebeigbe, A. B. (1991). Dietary salt loading attenuates endothelium-dependent relaxation in response to histamine but not to acetylcholine in rat aortic rings. Exp. Physiol.76: 135-138.

Onay-Ucar, E., Karagoz, A. and Arda, N. (2006). Antioxidant activity of Viscum album ssp. album. Fitoterapia 77: 556-560.

Perry, P. A. and Webb, R. C. (1991). Agonistsensitive calcium stores in arteries from steroid hypertensive rats. Hypertension 17: 603-611.

Sofola, O. A., Obiefuna, P. C. M. and Adegunloye, B. J. (1993). Contractile response of normotensive rat aorta to serum from saltloaded Sprague-Dawley rats. Pflügers Arch. Eur. J. Physiol. 423: 161-163.

Somlyo, A. P. and Somlyo, A. V. (1968). Electromechanical and pharmacomechanical coupling in vascular smooth muscle. $J$. Pharmacol. Exp. Ther. 15: 129-145.

Tenorio-Lopez, F. A., Valle Mondragon, L. D., Olvera, G. Z., Torres Narvaez, J. C. and Pastelin, G. (2006). Viscum album aqueous extract induces NOS-2 and NOS-3 overexpression in Guinea pig hearts. Nat. Prod. Res. 20: 1176-1182.

Ye, W., Nanga, R. P., Kang, C. B., Song, J. H., Song, S. K., and Yoon, H. S. (2006). Molecular characterization of the recombinant A-chain of a type II ribosome-inactivating protein (RIP) from Viscum album coloratum and structural basis on its ribosome-inactivating activity and the sugar-binding properties of the B-chain. $J$. Biochem. Mol. Biol. 39: 560-570.

Zuzak, T. J., Rist, L., Eggenschwiler, J., Grotzer, M. A. and Viviani, A. (2006). Paediatric medulloblastoma cells are susceptible to Viscum album (Mistletoe) preparations. Anticancer Res. 26: 3485-92. 